DOI: $10.17805 /$ trudy.2018.4.6

\title{
СОВРЕМЕННЫЕ ТЕХНОЛОГИИ И МЕТОДЫ ОПРЕДЕЛЕНИЯ РЕЗУЛЬТАТИВНОСТИ НАУЧНО-ИССЛЕДОВАТЕЛЬСКОЙ ДЕЯТЕЛЬНОСТИ
}

\author{
И. В. Кощиенко
}

Московский гуманитарный университет

Аннотация: Статья посвящена проблеме использования современных технологий и методов определения результативности научно-исследовательской деятельности преподавателей и обучающихся в вузе.

Ключевые слова: научно-исследовательская деятельность, информационные технологии; НИР; оценка результативности

\section{MODERN TECHNOLOGIES AND METHODS FOR DETERMINING THE EFFECTIVENESS OF RESEARCH ACTIVITIES}

\author{
I. V. Koshchienko \\ Moscow University for the Humanities
}

Аннотация: The article is devoted to the issue of using modern technologies and methods for determining the effectiveness of research activities of teachers and students at the University.

Ключевые слова: scientific research activity, information technologies; scientific research work; effectiveness evaluation

В современных условиях развития высшего образования одним из ключевых требований является необходимость оценки эффективности деятельности вуза с использованием наукометрических показателей, характеризующих его достижения в научно-исследовательской деятельности. Важно, что здесь возникает потребность в определении результатов преподавателей образовательной организации и качества подготовки обучающихся, а именно, оценки их конкретных научных достижений. Введение профессиональных стандартов и требование их тесной взаимосвязи с Федеральными государственными образовательными стандартами (ФГОС), через формирование профессиональных компетенций будущих выпускников направлено на развитие навыков проведения исследований, разработки инновационных продуктов. В этой связи возникает необходимость 
Научные труды Московского гуманитарного университета 2018 № 4

качественной организации научно-исследовательской деятельности, как преподавателей, так и обучающихся.

Успехи и сложности в развитии научного взаимодействия участников образовательных отношений активно исследуются. Довольно часто для объединения преподавателей и студентов выбирается единая тема научно-исследовательской деятельности кафедры, которая в дальнейшем распадается на множество самостоятельных исследований. Преподаватели транслируют свои результаты в материалах конференций, научных статьях, монографиях; студенты - в докладах на научных мероприятий, итогах выпускных квалификационных работах, магистерских диссертаций. Таким образом, ключевым в данном формате реализации совместной научной деятельности, является «обучение, в котором динамически моделируется предметное и социальное содержание профессионального труда, тем самым обеспечиваются условия трансформации учебной деятельности студента в профессиональную деятельность специалиста» (Бим-Бад, 2002: 127). Данный подход может реализовываться на всех уровнях современного образования - бакалавриат, магистратура, аспирантура.

В этой связи интересен опыт сетевого взаимодействия Российского педагогического университета им. А. И. Герцена (РПГУ) и Омского государственного педагогического университета (ОмГПУ). Например, участие обучающихся в научно-образовательных проектах кафедр, является в данных вузах традицией. Выполнение заданий, конкурсы и командная работа участников проектов создают новый контекст: профессионально-развивающий, в котором проявляют себя скрытые возможности и ресурсы всех образовательных программ кафедр. Новые виды деятельности, новые роли организатора научного мероприятия, участника, тьютора (при участии бакалавров, магистров, аспирантов или молодых преподавателей), позволяют по-новому взглянуть на свою настоящую и будущую профессиональную деятельность. Обязательная подготовка и возможная публикации статьи по теме исследования это одно из заданий научно-исследовательской работы обучающихся. Стиль и язык научной статьи, выступление с представлением доклада, участие в круглых столах, дискуссионных площадках, где присутствуют ведущие преподаватели кафедр, все это позволяет обучающимся почувствовать себя включенными в общее научное поле кафедральных исследований. Этот контекст является и развивающим, и деятельностным (Федорова, Чуркина, 2016: 162).

В Московском гуманитарном университете (МосГУ) в рамках участия в «Фестивале науки», а также проведения традиционной «Недели студенческой науки» в последние годы проходит целый ряд мероприятий (выставки научных достижений, открытые лекции, конференции и научные форумы), 
которые открывают для всех обучающихся новые горизонты деятельности и личностного, профессионального развития. Привлечение к процессу обучения работодателей, участие обучающихся в мероприятиях организуемых различными подразделениями МосГУ — это одно из условий, позволяющих студентам наших образовательных программ после их окончания успешно решать профессиональные задачи. Очень важно для будущих выпускников уметь транслировать необходимые сведения адресно, с учетом специфики различных групп социальных и профессиональных партнеров, уметь популяризировать научные знания по проблеме.

Следует согласиться с мнением ученых Кубанского государственного аграрного университета, что одним из важных показателей средств повышения качества работы профессорско-преподавательского состава кафедры является оценка работы на основании рейтинга по основным видам деятельности в течение определенного учебного периода. Авторы подчеркивают, что сегодня известно значительное количество методик рейтинговой оценки деятельности преподавателей и кафедры в целом, но в реальную вузовскую систему образования внедрено лишь небольшое их число. Во многом, это связано с материальным стимулированием преподавателя, которое должно выражаться в поощрении преподавателей кафедр за эффективные результаты работы, направленные на успешную аккредитацию вуза (Трубилин, Григораш, 2012: 19).

Безусловно, в контексте результативности научно-исследовательской деятельности вуза в целом и преподавателей в частности, именно рейтинговая оценка работы кафедры является одним из эффективных средств. Эта оценка является условием осуществления анализа причин возникающих недостатков в работе и устранения их путем совершенствования планирования работы, проведения дополнительных организационно-методических мероприятий. Следует согласиться с позицией авторов, что все эти действия в целом направлены на повышение качества учебного процесса, что, в конечном результате, позволит готовить высококвалифицированных специалистов (там же: 20).

Одной из современных технологий оценки результативности НИР преподавателей и студентов является портфель достижений - «портфолио».

Для обучающегося принятый портфолио представляет собой подборку набора работ, целью которой является представления его образовательных достижений (Хузина, 2010: 99). Исследовательскую работу студентов условно можно разделить на учебную и научную деятельность. Важно, что данная работа направлена на пополнение и закрепление, а затем углубление и расширение знаний студентов. Введение навыков исследовательской работы в имеющихся формах позволяют развивать у каждого студента способность 
Научные труды Московского гуманитарного университета 2018 № 4

к познавательной деятельности, самостоятельности и инициативности, желание совершенствовать свои творческие способности. Примечательно, что увеличение самостоятельной составляющей работы студентов позволяет формировать у них навыки ответственного решения исследовательских и практико-ориентированных задач, а также стимулировать их участие в научно-организационных мероприятиях (научные конференции, круглые столы, семинары). Портфолио студента формируется соответствующим образом, должно отражать его плодотворное взаимодействие с научным руководителем, другими преподавателями вуза, и, что важно, помогать устанавливать тесную связь с потенциальными работодателями. Безусловно, при формировании портфолио научных достижений студентов, необходимо опираться на принципы, используемые в данной технологии: во-первых, добровольность участия в данном проекте; во-вторых использование возможности самостоятельной оценки обучающимся результатов овладения определенными видами научной деятельности; в-третьих определенный регламент при заполнении данных; в-четвертых структуризация, логичность и достоверность информации, представляемой в «Портфолио».

Поскольку НИР для преподавателя вуза является одним из основных видов деятельности, то и его портфолио следует формировать, в первую очередь, результатами его научных достижений. Среди них: квалификационные характеристики (ученая степень, звание); научное руководство обучающимися всех уровней высшего образования; наличие государственных и ведомственных наград, почетных званий; сведения обо всех видах публикаций и прежде всего в рецензируемых журналах, международных и отечественных конференциях; сведения о подготовке кандидатов и докторов наук, о подготовке обучающихся-победителей студенческих научных конкурсов; об объемах НИР в рамках выполненных грантов научных фондов, а также сведения о выполнении различных видов научно-исследовательской и организационной работы со студентами.

Опираясь на имеющийся опыт работы, портфолио научных достижений студента реализуется в МосГУ через его личный кабинет на сайте университета, доступ в который студент получает с первых дней пребывания в нем. Также в виде информационной базы данных доступно и портфолио достижений научно-исследовательской и научно-методической деятельности преподавателя.

Таким образом, современные технологии и методы определения результативности научно-исследовательской деятельности позволяют обеспечивать не только трансляцию индивидуальных достижений профессорско-преподавательского состава вуза, но и активно включать обучающихся в исследовательскую деятельность, развивая при этом научное взаимодей- 
ствие разных поколений исследователей, а также формируя профессиональные компетенции будущих выпускников.

\section{СПИСОК ЛИТЕРАТУРЫ}

Бим-Бад, Б. М. (2002) Педагогический энциклопедический словарь. М. : Большая Российская энциклопедия. 528 с.

Федорова, Н. М, Чуркина, Н. И. (2016) Организация научно-исследовательской деятельности студентов магистратуры в сетевом формате // Вестник Сибирского института бизнеса и информационных технологий. № 4. С. 161-164.

Трубилин, А. И., Григораш, О. В. (2011) Система оценки качества деятельности преподавателей и кафедры // Экономика образования. № 2. С. 19-23.

Хузина, С. А. (2010) Технология «портфолио» как основа рейтинга научных достижений преподавателей и студентов вуза // Ученые записки университета им. П. Ф. Лесгафта. № 11 (69). С. 98-103.

Дата поступления: 15.08.2018 2.

Кощиенко Ирина Васильевна - кандидат педагогических наук, доцент кафедры педагогики и психологии высшей школы Московского гуманитарного университета. Адрес: 111395, Россия, г. Москва, ул. Юности, д. 5. Тел.: +7 (499) 374-60-41. Эл. адрес: ds2723@mail.ru

Koshchienko Irina Vasilievna, Candidate of Pedagogy, Associate Professor, Department of Pedagogy and Psychology of Higher School, Moscow University for the Humanities. Postal address: 5, Yunosti St, Moscow, Russian Federation 111395. Tel.: +7 (499) 374-60-41. E-mail: ds2723@mail.ru

\section{Для цитирования:}

Кощиенко И. В. Современные технологии и методы определения результативности научно-исследовательской деятельности [Электронный ресурс] // Научные труды Московского гуманитарного университета. 2018. № 4. URL: http://journals.mosgu.ru/trudy/article/view/810 (дата обращения: дд.мм.гг.). DOI: 10.17805/trudy.2018.4.6 